UDC 378.477

\title{
STUDENTS' INDIVIDUAL CHARACTERISTICS AND THEIR CONSIDERATION IN TEACHING FOREIGN LANGUAGES
}

\author{
N. E. Doronkina, O. V. Ivasiuk \\ Kyiv, National Technical University of Ukraine "Kyiv Polytechnic Institute" \\ ndoron@ukr.net, english_ov@ukr.net
}

\begin{abstract}
The article deals with the ways of finding approaches to teaching foreign languages to students with different abilities within one educational process in higher technical educational institutions. To recognize different types of intelligence, the criterion of predominating perceptive channel or perceptive modality and the theory of multiple intelligences have been used. According to the former, visual, auditory and kinesthetic types are determined. The latter comprises verbal, logical, interpersonal, intrapersonal and naturalistic intelligences. The author describes the peculiarities of each type of intelligence as well as analyzes the methods and means of teaching foreign languages in accordance with them. The project-based and problem-based learning are considered to be effective techniques to involve all the students with different psychological characteristics in educational process. The former contains teacher centered and student centered approaches, which are described and compared in the article. Their advantages and disadvantages are shown. In the field of problem-based learning, alternative and auxiliary educative methods and forms are taken into account. The stages of individual educational approaches corresponding to three phases of cognitive acts are discussed. Besides, the methods of problem-based learning are mentioned and analyzed.
\end{abstract}

Key words: perceptive modality, project-based learning, problem-based learning, multiple intelligences theory, educational methods, predominating perceptive channel.

Introduction. In the process of education a teacher usually faces the problem of teaching students of different psychotypes in one classroom. To improve the effectiveness of learning, it is necessary to take into account students' individual characteristics.

The purpose of the article is to outline the peculiarities of using the multiple intelligences theory in teaching foreign languages at technical higher educational institutions.

The types of students' intelligence. Scientists differentiate the following perceptive channels or perceptive modalities: visual, auditory and tactile [1, p.131]. One of them usually predominates in most people i.e. it responds to signals of environment faster than the others. Therefore, perceptive modality is one of the most important personality characteristics, according to which we can mark visual, auditory and kinesthetic types of student. These correlate with three types of intelligence. But according to H. Gardner's theory, there are also 5 types of mental abilities: verbal, logical, interpersonal, intrapersonal and naturalistic [2, p.125-330]. Each of them has its own strengths, areas, preferences, needs and ways of learning [4, p.32-41].

People with visual intelligence often use words and expressions associated with images and impressions, e.g. to see, to fancy etc. They notice the details of everything that can be seen, i.e. shapes, colors, outlines. So, teachers can amplify their intelligences by utilizing such visual materials as pictures, videos, maps, diagrams and art activities. Particularly useful are picture dictionaries. In teaching the visual contact is necessary. Besides, such people learn better watching somebody carry out different actions. Information to be memorized should be written or printed. Internet blogs may be used as much as possible. One of the visual learners' problems is so called audible barrier. It's difficult for them to recognize spoken texts. To dispose of that disadvantage one should be involved in active practice of listening. The first step of such learning is working with audio materials in which native speakers talk slowly. The next step is watching videos with English subtitles.

Individuals with predominating auditory channel typically belong to musical intelligence type. They learn best through reading aloud or conversations such as discussions. In speaking they pay attention to voices, intonation, timbre, rhythm and manner of speech picking them up easily. The rules to be studied should be walked through inwardly. Thus, vocabulary and grammar are learned in the context. On listening English songs, audio lessons or podcasts it is better to repeat them trying to imitate the speakers or singers. However, musical intelligence students usually have some spelling problems. So they ought to focus specifically on corresponding exercises. 
People, having kinesthetic intelligence, investigate their environment being in motion. They get information through the body sensations. They take notice of moving objects, people's behavior and actions. So, in conversation they often gesticulate and use the words with the meaning of motion. To memorize a new rule, they are given vivid examples. When kinesthetic learners study new words, they imagine the meaning, i.e. objects, actions, properties etc. Since they enjoy physical activities, in particular moving around, it is important for them to be in motion during the process of study. Keeping a diary and describing as many events as possible is also useful. Teachers can strengthen kinesthetic intelligence through improvisation, practical activities and physical relaxation exercises.

Despite the fact that there are three perception channels, an individual can process data in four ways. The forth one is of logical or digital nature. It is an inner monologue associated with words and numbers. People with the ability to collect, organize and analyze information to predict and conclude are characterized by logical or mathematical intelligence. They are considered to be quite a rare character type although such persons are often found among the students of technical educational institutions. Researches, scientists, programmers and famous chess players often belong to this type. They rarely express emotions, feelings. This type is oriented to reasoning, sense and functionality. Such people seem to be unfeeling but knowing a lot. They tend to comprehend and unscramble all necessary information. However, actually they are sensitive. Their vocabulary includes the words associated with logic, e.g. to analyze, to conclude, to exclude etc.

When the students are strong in mathematical intelligence and conceive the world due to logical understanding, the teacher ought to communicate with them with the help of logical arguments. The progress in this area of intelligence can be encouraged by using critical thinking activities. Cognitive stretch exercises, logical puzzles and sequential presentation of the subject would be helpful. For example, grammar rules should be introduced in the form of formulas.

The ability to operate and understand languages is connected with verbal or linguistic intelligence. It is peculiar to everyone at some level. It contains different kinds of verbal communication, for example writing and speaking. This ability is very important for scientists because they must take part in conferences and write scientific tractates. Like people having kinesthetic intelligence, linguistic intelligence learners should keep a diary. Besides, they need to practice debates and discussions because rhetorical and oratory skills are important for scientists. Various word games are also helpful.

Individuals with strong empathy for other individuals are said to possess interpersonal intelligence. It means that they easily recognize and respond to moods, feelings and emotions of other people. Naturally, it results in fine communication and interaction skills. So, these students would be good at group work including games, discussions, interviews etc. Teachers ought to encourage their taking part in speaking clubs and community events.

Unlike the interpersonal intelligence, the intrapersonal intelligence is inherent to people who understand their feelings and emotions, know their own advantages and disadvantages and must set reasonable goals. So, they prefer working independently and learn best through writing articles, essays, keeping journals or blogs to express their feelings and ideas. The feature of this intelligence is to embrace the use of all others since it is necessary to strengthen individual abilities.

Naturalistic intelligence means the ability of recognizing and classifying, especially the objects of nature, i.e. plants, animals and minerals. The advantage of this kind of students is deep understanding of nature. So, the teacher can boost the effectiveness of learning by encouraging their interest. The education process for such learners must include classifying, comparing and ordering exercises dealing with the relationships among different objects of nature.

There is another type of intelligence which refers to people who think over the concepts of life and death. Naturally, those people enjoy philosophy. As a rule they are not numerous in technical educational institutions.

The approaches to the problem solution. The educators of different countries propose various ways of implementing the theory of multiple intelligences in the process of education. One of them belongs to the area of project-based learning. A common task is assigned to a group of students who work together to create a resulting product. In this case each of them can exhibit the 
strengths and reduce the weaknesses. For example, students are involved in certain scientific investigation or art supplies creating.

There are two methods to introduce the multiple intelligences theory into an educational process [5]. One of them is teacher centered. In this case the materials and activities of the lesson are designed for different intelligences. The disadvantage of this approach is limitation of the number of intelligences to three. Another method is known as student centered. In this case, students compose different materials to demonstrate their mastering of the subject. Project-based and collaborative learning would be an asset. There is no need for students to do all the exercises because the activities for all intelligences are optional. Both methods activate all intelligences.

Taking into account different intelligences is also possible in the area of problem-based learning, particularly, individual educational path building [3, p.16-24]. The essence of problembased pedagogy is that the new material is presented through creation of a problem situation.

Thus, the process of learning takes place in the form of solving a complex of tasks prepared by the teacher. As the students achieve the purpose, they obtain the skills, knowledge and experience helping them to become active creative independent persons.

Problem-based learning is put into practice in various ways, e. g. depending on the degree of students' independence the following are developed: the explanatory and illustrative, reproductive, heuristic, investigatory, problematic presentation methods. At the explanatory and illustrative method of learning, the teacher gives ready-made information to students explaining and illustrating it. In case of the reproductive method, students carry out the actions following the model given. The problematic presentation method refers to the format of lessons in which the teacher states the problem and shows how to solve it and the learners follow the logic of solution. The heuristic method is to divide the problem into subproblems. Solving them, the students gradually move to the goal. Finally, at the introductory method the students define educational problems and solve them by means of research and creative activity.

To choose the educational path, it is necessary for the teacher and the student to work together. The united actions are directed to the students' development of the skills of independent studying including task assignment, choice of methods, forms, means and content of learning. Problem-oriented learning includes three stages corresponding to three phases of a cognitive act: understanding the problem, its solution and conclusion. Thus, students' motivation and task assignment serve as the first stage. The process of learning itself accords with the phase of solving the problem. Finally, students assess their results.

In teaching English at technical universities, the elements of all approaches mentioned above are used. In particular, the author often practices role plays implementing visual, audial, logical and interpersonal intelligences. An example of a student centered lesson is an excursion followed by a discussion. Students having verbal intelligence, make introductory reports. Then, during the excursion, all perceptive modalities are involved. In discussion students with strengths in interpersonal and intrapersonal intelligences have the opportunity to manifest themselves. As for individual educational paths, they are an essential part of educational process in any educational institution because students not only have different intelligences, but also different levels of competence.

Conclusion. The theory of multiple intelligences implementation into educational process promotes effective learning. However, the results greatly depend on the number of students in the group and the number of types they belong to. Not all intelligences can be utilized in equal measures. So, this factor must be taken into account on the stage of learning group creation.

\section{REFERENCES}

1. Ананьев Б. Г. Психология и проблемы человекознания / Б. Г. Ананьев. - М.: Изд-во «Институт практической психологии», 1996. - 384 с.

2. Гарднер Г. Е. Структура разума: теория множественного интеллекта / Г. Е. Гарднер. - М.: Вильямс, 2007. $-512 \mathrm{c}$.

3. Сысоев П. В. Обучение по индивидуальной образовательной траектории / П.В. Сысоев // Теория и методика профессионального образования. - 2013. - № 2(16). - С. 13-24.

4. Armstrong T. Multiple Intelligences in the classroom / T. Armstrong. - Alexandria: ASCD, 2009. -246 p. 
5. Giles E. Multiple intelligences and learning styles / E. Giles, S. Pitre, S. Womack // Association for Educational Communications and Technology http://epltt.coe.uga.edu/index.php?title=Multiple_ Intelligences_and_Learning_Styles.

\section{REFERENCES}

1. Ananiev, B.G. (1996). Psychology and problems of mankind. Moscow, Russia: Institut prakticheskoy psihologiyi [in Russian]. Russian].

2. Gardner, G.E. (2007). The structure of reason: Multiple Intelligences theory. Moscow, Russia: Vilyams [in

3. Sysoyev, P.V. (2013). Individual education path. Teaching methodology in higher education, 2(16), 13-24 [in Russian].

4. Armstrong, T. (2009). Multiple Intelligences in the classroom. Alexandria, USA: ASCD.

5. Giles, E., Pitre, S., Womack, S. (2014). Multiple intelligences and learning styles. E-Journal of Association for Educational Communications and Technology. Retrieved http://epltt.coe.uga.edu/index.php?title=Multiple_Intelligences_and_Learning_Styles [in Russian].

\section{Н. С. Доронкіна, О. В. Івасюк. Врахування індивідуальних особливостей студентів у викладанні англійської мови.}

Стаття присвячена шляхам вирішення проблеми об'єднання студентів з різними здібностями в одному процесі навчання іноземної мови у вищому навчальному закладі технічного спрямування. Для того, щоб виокремити різні типи інтелекту студентів, використовується теорія множинного інтелекту Гарднера. У якості критерію такого розподілу розглядається домінувальний перцептивний канал або перцептивна модальність, відповідно до якого розрізняють візуалів, аудіалів та кінестетиків, що збігається з трьома видами інтелекту. Теорія множинного інтелекту додає до цієї класифікації такі типи, як: вербальний, логічний, інтерперсональний або внутрішньоособистісний, інтраперсональний або міжособистісний та натуралістичний. Описано особливості кожного з типів та відповідні методи навчання. 3 метою ефективного залучення названих типів студентів до навчального процесу запропоновано такі шляхи його побудови, як проектно-орієнтовне навчання та проблемно-орієнтоване навчання. У першому випадку розглянуто два підходи,а саме: заняття, у центрі яких знаходиться викладач та заняття, у центрі яких знаходиться студент. 3 погляду проблемно-орієнтованого навчання розглянуто метод побудови індивідуальної освітньої траєкторії та метод занурення студентів у штучно створену проблемну ситуацію. Також згадано та порівняно методи проблемно-орієнтованого навчання у різних класифікаціях. Обговорено три стадії побудови індивідуальної освітньої траєкторії, які відповідають трьом фазам когнітивного акту. Висвітлено елементи згаданих вище підходів, які широко використовуються викладачами іноземної мови у сучасний вищих навчальних закладах.

Ключові слова: перцептивна модальність, проектно-орієнтоване навчання, проблемно-орієнтоване навчання, теорія множинного інтелекту, методи навчання, домінуючий канал сприйняття інформації.

\section{Н. Е. Доронкина, О. В. Ивасюк. Учет индивидуальных особенностей студентов в преподавании} английского языка.

Статья посвящена путям решения проблемы объединения студентов с различными способностями в одном учебном процессе. В соответствии с доминирующим каналом получения информации или перцептивной модальностью и теорией множественного интеллекта выделено восемь видов интеллекта студентов. Описаны особенности каждого вида интеллекта и методы обучения, которые им подходят. В целях эффективного вовлечения названных видов интеллекта в учебный процесс, предложены такие пути его построения как проектно-ориентированное обучение и проблемно-ориентированное обучение. В первом случае рассмотрены два подхода, а именно: уроки, в центре которых находится преподаватель и уроки, в центре которых находится студент. Также описаны методы проблемно-ориентированного обучения в разных классификациях. В рамках решения поставленной задачи для максимального учета способностей студентов описан метод построения индивидуальной образовательной траектории.

Ключевые слова: перцептивная модальность, проектно-ориентированное обучение, проблемноориентированное обучение, теория множественного интеллекта, методы обучения, доминирующий канал восприятия информации. 